\title{
Information Literacy Skills of Arts Subject Teachers in Lagos State Senior Secondary Schools Nigeria
}

\author{
Durodolu, Oluwole Olumide; Adekanye, Elizabeth Adetoun; \\ Olorunfemi, Doreen Yemisi \\ University of Lagos Library, Akoka, Lagos \\ University of Lagos Library, Akoka, Lagos \\ University of Zululand, KwaDlangezwa South Africa.
}

\begin{abstract}
Information literacy is considered an essential skill that every society is expected to acquire in the modern knowledge-based global economy. Schools play the vital role of producing future citizens who are expected to be creative, critical thinkers, and lifelong learners. To accomplish this objective, schools are expected to implement information literacy programmes that are explicitly designed to equip students and teachers with the necessary aptitude that would help them become independent and active learners and workers. Information literacy is the adoption of appropriate method to identify, through whatever channel or medium, information well fitted to information needs, leading to wise and ethical use of information in society.

The design of the research was descriptive survey in which few units were selected and examined and on that basis make inference about the population. Perception scale containing statements about information literacy was presented to respondents. A total of one hundred and fifty (150) copies of the questionnaire designed for the study were administered on the secondary school teachers handling arts courses in Lagos State, out of which only one hundred and twenty (120) copies were returned with useful responses, giving a response rate of $80.0 \%$.

At the end of the research is was discovered that teachers in Lagos State senior secondary schools have a positive perception towards the relevance of information literacy skills in enhancing their implementation of humanities curricula, 36.6\% of teachers are qualified to teach at senior secondary school level, majority of the teachers are experienced because they have been teaching for more than six years, the research also revealed that only (44.2\%) of the teachers. possess the skill of determining when information is needed for the implementation of the curriculum; only $39.2 \%$ possess the skill of accessing information; $50.8 \%$ have the skill of identify the sources of information and only 42.5 possess the ability to use information for the benefits of curriculum implementation, and finally, only (44.2\%) of the teachers possess the skill of determining when information is needed for the implementation of the curriculum; only $39.2 \%$ possess the skill of accessing information; $50.8 \%$ have the skill of identify the sources of information and only 42.5 possess the ability to use information for the benefits of curriculum implementation.
\end{abstract}

Keyword: Information literacy, Information technology, Lifelong learning, Information Abundance, Teaching and Learning

\section{Introduction}

Information literacy is considered an essential skill that all citizens should acquire in today's knowledge-based global economy. Schools play the vital role of producing future citizens who are expected to be creative, critical thinkers and lifelong learners. To achieve this objective, schools are required to implement information literacy programmes that are explicitly designed to equip students with the necessary aptitude that would help them become independent active learners and workers. (Mokhtar, Majid and Foo, 2004) Information literacy has been described as the ability to search, locate, appraise and ultimately use information or facts, and thereafter create useful knowledge from it (American Library Association (ALA), 1989). Although many definitions of information literacy have been offered by many authors, they all share a common theme derived from the definition advanced by the American Library Association (ALA)

Information literacy is acknowledged as one of a range of knowledge, values, skills and understanding that is required for lifelong learning. To become a lifelong learner, individuals must have access to needed information and must also be able to judge the quality of the information to which they are exposed (Candy, 2002). Information literacy has become a significant building block in education today. With increasing amounts of information, brought about in part by developments in technology for producing, organizing, storing and accessing information, and the increasing importance of information in personal and professional life, there 
is a need to know when and why information is needed, where to find it, and how to evaluate, use and communicate it in an ethical manner (CILIP 2004): that is, to be information literate.

However, these skills are not innate in scholars; they have to be learned. The most viable place for learning information literacy skill is the school: as children are in their formative years, they represent a captive audience, and there is an opportunity for structured learning experiences. In many schools, the responsibility of imparting these skills is assigned to one or more of the teachers who manage the library. This practice has been emphasized by many authors, including Eisenberg (2002), who believed that libraries and library media teachers should be right in the middle, working in partnership with classroom teachers, administrators and the community to ensure that students are effective users of ideas and information. The American Library Association and the Association for Educational Communications and Technology (1998) affirmed the roles and responsibilities of library and media teachers as teachers, instructional partners, information specialists and program administrators. As information specialists, library and media teachers should be able to provide expertise in acquiring and evaluating information resources in all formats, as well as be able to educate students to locate access and evaluate information within and beyond the library media resource centre. The recently released American Association of School Librarians Standards for the 21st Century Learner (2007) also emphasizes the foundational belief that school libraries are essential to the development of learning skills.

The growth in number and variety of new media technologies has signaled a major revolution in teaching and learning processes (Duggan, 2001). Institutions of learning are progressively adopting ICT as tools for learning, collaboration, communication, curriculum and staff development. New media for education and training are more critical today than ever before, since new means of improving instructional methods are triggering a change in the delivery of education (Pajo and Wallace, 2001). This development influences university and corporate practices and policies and changes our conceptualization of teaching and training.

Competency in the new media of the Internet is essential for participating in contemporary society. Students' preference for the Internet and other related technology does not mean they are fully competent in the media literacies; instead, there is a pressing need for schooling to include media instruction in these new literacies as well as more effective and meaningful assimilation of the Internet in learning (Asselin and Moayeri, 2010). As Internet access increases, youths turn to the Internet (not books) for information (Rowlands and Nicholas 2008). At the same time, the amount of information available on the Internet is exploding and the organization of this information becomes increasingly complex, therefore the need to equip student on appropriate use of this technology becomes paramount.

The progressively more convoluted world in which we live now contains an abundance of information choices in print, electronic, image, spatial, sound, visual and numeric. The issue is no longer one of not having enough information; it is the opposite of what is formerly obtainable: that is, too much information in various formats and not all of equal value. In an era of more than 17 million Internet sites, three billion Web pages and more than a million items in a typical medium-sized academic library, the ability to act confidently (and not be overwhelmed by information overload) is critical to academic success and personal self-directed learning (Rockman, 2004).

In addition to using technological resources, learners also reach beyond classroom walls into their local communities for the rich supply of materials and authoritative information provided by businesses, social services agencies, citizens' groups, and public and university libraries. The mass media - cable and network television, radio broadcasts and other national and international print and electronic services - provide yet another rich source of information (Hancock, 2003).

In the same vein, Behrens (1990) holds that person who is library literate cannot be regarded as fully information literate. Library literacy is a sub-set of information literacy. Libraries are not the only information and knowledge resources available. To term a library orientation programme a course - engendering, information literacy skill is misleading. Library skills tend to focus on the ways of locating information or the instrumental aspects of retrieval. They do not usually cover the broader contextual elements and the higher-level analytical skills necessary to effectively mine and utilize information in a manner which will withstand appropriate scrutiny.

Most people today are keenly aware of the sudden large amount of information they are bombarded with from the time they wake up to their favorite morning talk show until the time they turn off the late-night news. Books, newspapers, professional journals, e-mail from colleagues and newsletters from community organizations add to the volume of information flooding people's lives. But more information does not necessarily mean better information. If one reads the headlines, there may be inaccuracies, exploitation and deception which have grown along with the speed and magnitude of information available (Australian Library and Information Association, 2003).

Individuals who are conversant with finding, evaluating, analyzing, integrating, managing and conveying information to others efficiently and effectively are held in high esteem. These are the students, workers, or citizens who are most successful at solving problems, providing solutions, and producing new ideas 
and directions for the future. They are lifelong learners. Today's students, then, can benefit throughout their lives from learning a process for becoming information literate - that is, acquiring the skills required to intelligently and systematically find, interpret, select, evaluate, organize and use information for a specific purpose (Rockman, 2004).

According to Obama (2009) learners are inundated with vast amounts of information. Twenty-four hour news and thousands of global television and radio networks, coupled with an immense array of online resources, have challenged old perceptions of information management. Rather than merely possessing data, it is also important to learn the skills necessary to acquire, collate and evaluate information for any situation. This new type of literacy also requires competence in communication technologies, including computers and mobile devices that can help in day-to-day decision making. Information literacy skills are necessary to effectively navigate the Information Age.

Finding information may be easy but the ability to evaluate this information is also very important (Obama, 2009). Over the past decade, crises of authenticity have emerged because so many people can now publish an opinion or perspective, whether true or not, and have that opinion amplified within the information marketplace, and at the same time have unprecedented access to the diverse and independent sources of information as well as institutions such as libraries and universities, which can help separate truth from fiction and signal from noise.

Obama, (2009) also cautioned institutions of learning to adjust to these new realities. In addition to the basic skills of reading, writing and arithmetic, it is equally important that students should be given the tools required to take advantage of the information available to them. The ability to seek, find and decipher information can be applied to countless life decisions, whether financial, medical, educational or technical.

\section{Statement of the Problem}

The study is designed to investigate the extent of development of information literacy skills and to suggest possible ways to incorporate the skills into the secondary school curriculum of Lagos State of Nigeria in order to bring about improved service delivery.

Teachers, librarians, information specialists, curriculum experts and parents have observed that there are major gaps in students' information skills and the reason can be traceable to the information literacy ability of the teachers. They are of the opinion that most students know very little about basic library tools and information literacy technique. With no tangible proof, however, the observations of these specialists remain hypothetical.

Teachers just like many professionals need information for a multiplicity of activities especially in this modern time when information is abundantly available from many sources and format, with the aim of meeting the information needs of everybody. There is a sudden increase of information resources and the challenge of using these resources successfully and conscientiously is obvious. In using the available information resources, teachers lack skill in accessing, utilizing, and evaluating information, which militate against the valuable use.

The goal of this study is to verify whether these impressions have validity and to determine whether students in secondary school have the ability to locate, retrieve, process and evaluate information.

\section{Objectives of the Study}

The Major objective of this study is to investigate the information literacy skill of secondary school teachers of humanities subjects and the way they implement the curriculum of the subjects. Specifically, the study tends to investigate:

teachers' perception about the need for information literacy skills in the implementation of senior secondary school humanity subjects curriculum in Lagos State.

1 academic qualification and years of teaching experience of teachers handling humanity subjects in senior secondary schools in Lagos State.

2 proportion of humanity subject teachers in Lagos State senior secondary schools who are professionally qualified.

3 whether humanity subject teachers in Lagos State possess the information literacy skill, that is:

a) Ability to identify when information is needed

b) Ability to identify and evaluate sources of information

c) Ability to access information

d) Ability to utilize information

e) Ability to ethically use information

4 type of information resources that humanity subject teachers in Lagos State access for teaching purpose. 


\section{Research Questions}

1. What is the perception of teachers about the need for information literacy skills in the implementation of senior secondary school humanity subjects' curriculum in Lagos State?

2. What is the academic qualification and year of teaching experience of teachers handling humanity subjects in senior secondary schools in Lagos State?

3. What proportion of humanity subjects teachers in Lagos State secondary school are professionally qualified?

4. Do the humanity subject teachers in Lagos State possess the information literacy skill, that is:

a) Ability to identify when information is needed

b) Ability to identify and evaluate sources of information

c) Ability to access information

d) Ability to utilize information

e) Ability to ethically use information

5. What type of information resources do the humanity teachers in Lagos State access for teaching purpose?

\section{HYPOTHESES}

The following hypotheses guided the conduct of this study and were tested at 0.05 level of significance: $\mathrm{H}_{01}$ :- There is no significant relationship between humanity teacher's perception of importance of information literacy to secondary school humanity subject teaching and their information literacy skills.

$\mathrm{H}_{02}$ :- There is no significant relationship between humanity teacher's perception of importance of information literacy to secondary school students and the utilization of information literacy skill on the implementation of humanity curricula.

$\mathrm{H}_{03}$ :- There is no significant relationship between humanity teacher's access to information literacy and the utilization of information literacy skill on the implementation of humanity curricula in senior secondary schools in Lagos State

$\mathrm{H}_{04}$ : - There is no significant relationship between humanity teacher's information literacy acquisitions and the utilization of information literacy skill on the implementation of humanity curricula in senior secondary schools in Lagos State.

\section{Significance of the Study}

This study is significant for a number of reasons. Finding will be useful to identify the level of information literacy skills among teachers. Also finding will provide a snapshot of the knowledge and levels of information literacy, as well as information on the current needs of these teachers. This research finding will also determine whether the teachers need any further information literacy programmes or training. At the same time, findings of this research will help to provide significant feedback on teachers' information literacy to the Ministry of Education in the state. The Ministry has been making considerable efforts in providing substantial resources for the development of information literacy in the schools. This study will provide useful information on whether there is a need for additional resources or a change of strategy.

Finding will also be very useful to the curriculum developers. In enabling them to incorporate the acquisition of information literacy skill programme into the curriculum of secondary schools in Lagos State, Nigeria.

The study would be very beneficial to policy makers, teachers and public-spirited groups, as they come to realize the several benefits of information literacy and how it can enhance the performance of teachers and students and also make them competent lifelong learners, where they are in a better position to bring about positive development to education system in the state.

The study would also be very helpful for future researchers, as it could present a template for further research.

This study will also provide an empirical evidence to justify whether or not it is important for all the teachers in Lagos State to be educated about information literacy and the effect it will have on their productivity in the classroom.

\section{Scope of the Study}

This research is limited to a sample of teachers handling courses in the humanities in senior secondary schools in Lagos State of Nigeria. Lagos is a densely-populated urban state, fairly reflective of the variation in the country. For the purpose, this research targeted 8,329 teachers from 298 schools in 6 educational districts. 
The study focused on the level of information literacy skills of teachers in senior secondary school in Lagos State. That is to examine the ability of teachers to determine when information is needed, access information at various sources and different format, evaluate diverse information, utilize information in a productive manner and use information ethically.

\section{Methodology}

The design of the research was descriptive survey in which few units were selected and examined and on that basis make inference about the population. In this survey, variables were observed as they occur through people's opinion.

\section{Sample and Sampling Technique}

The sampling technique is a three-stage sampling in which the first stage was stratified random sampling and the second and third stages were simple random sampling.

A sample of six (6) Local Governments was selected from twenty (20) Local Governments in Lagos State. These are called Primary Sampling Units (PSUs). To do this, Lagos State was divided into six (6) Educational District (EDs). The first-stage sampling was to select one local government out of three (3) or four (4) local government in each Educational District (ED).

The second stage sampling comprise of a few secondary schools at Random from all the schools in selected local government and the third stage sampling was a selection of some teachers out of all the teachers in a selected secondary schools.

Selected local secondary schools are called Secondary Sampling Unit (SSU). All the responding units in each SSU (Teachers) were given the questionnaires to fill.

Population of Secondary School Art Teachers in Lagos State, Nigeria.

\begin{tabular}{|c|c|c|}
\hline District & Local Government Area & Number \\
\hline 1 & Agege & 80 \\
\hline & Alimosho & 30 \\
\hline & Ifako - Ijaye & 57 \\
\hline & Ikorodu & 49 \\
\hline & Kosofe & 86 \\
\hline 3 & Shomolu & 39 \\
\hline & Epe & 26 \\
\hline & Eti - Osa & 28 \\
\hline & Ibeju - Lekki & 10 \\
\hline & Lagos Island & 54 \\
\hline & Apapa & 69 \\
\hline & Lagos mainland & 55 \\
\hline & Surulere & 64 \\
\hline & Ajeromi/Ifelodun & 80 \\
\hline & Amuwo-Odofin & 67 \\
\hline & Badagry & 111 \\
\hline
\end{tabular}

Source: Directory of Lagos State Ministry of Education Annual School census report 2011/2012

\section{Data Analysis and Result}

This paper focused on the analysis of data, interpretation of data and discussion of findings. A total of one hundred and fifty (150) copies of the questionnaire designed for the study were administered on the secondary school teachers handling arts courses in Lagos State, out of which only one hundred and twenty (120) copies were returned with useful responses, giving a response rate of $80.0 \%$. This response rate was considered adequate for this study. This chapter has been divided into three sections. Section one introduces the chapter while section two described the demographic distribution of respondents. The third section was on the research questions and hypothesis testing.

The data gathered from the returned copies of questionnaire were used for this study and discussed serially according to the relevant statistical of inferential descriptive statistics of frequency and percentage, and tested hypotheses with chi-square at 0.05 level of significance. This report was on information literacy skill of teachers and secondary school curriculum implementation in the Humanities in Lagos State Nigeria. 


\section{Answers to the Research Questions}

Research Question 1: What is the perception of teachers about the need for information literacy skills in the implementation of senior secondary school humanity subjects' curriculum in Lagos State?

Table 1: Teachers' Perception about the need for information literacy skills

\begin{tabular}{|c|c|c|c|c|c|c|}
\hline Variable & S D & $\mathrm{D}$ & A & S A & Mean & Std. D \\
\hline $\begin{array}{l}\text { I need information literacy skill to be an effective } \\
\text { teacher }\end{array}$ & $\begin{array}{l}13 \\
(10.8)\end{array}$ & $12(10.0)$ & $\begin{array}{l}45 \\
(37.5)\end{array}$ & $\begin{array}{l}50 \\
(41.7)\end{array}$ & 3.10 & .97 \\
\hline $\begin{array}{l}\text { There is no relationship between my level of } \\
\text { information literacy skills and job performance }\end{array}$ & $\begin{array}{l}49 \\
(40.8)\end{array}$ & $52(43.3)$ & $\begin{array}{l}17(14 . \\
2)\end{array}$ & $2(1.7)$ & 1.77 & .75 \\
\hline $\begin{array}{l}\text { I need special training on how to effectively use } \\
\text { the internet }\end{array}$ & $9(7.5)$ & $20(16.7)$ & 48(40. & $43(25.8$ & 3.04 & .91 \\
\hline $\begin{array}{l}\text { I need training on how to use academic electronic } \\
\text { databases }\end{array}$ & $7(5.8)$ & $17(14.2)$ & $\begin{array}{l}69(57 . \\
5)\end{array}$ & $27(22.5$ & 2.97 & .78 \\
\hline I need training on the proper use of the library & $\begin{array}{l}25 \\
(20.8)\end{array}$ & $39(32.5)$ & $\begin{array}{l}44(36 . \\
7)\end{array}$ & $12(10.0$ & 2.36 & .92 \\
\hline $\begin{array}{l}\text { I need information literacy skill to effectively use } \\
\text { a library }\end{array}$ & $\begin{array}{l}23 \\
(19.2)\end{array}$ & $26(21.7)$ & $\begin{array}{l}64(53 . \\
3)\end{array}$ & $7(5.8)$ & 2.46 & .87 \\
\hline $\begin{array}{l}\text { I need information literacy skill to effectively } \\
\text { retrieve information in any format from any } \\
\text { source }\end{array}$ & $\begin{array}{l}13 \\
(10.8)\end{array}$ & $33(27.5)$ & $\begin{array}{l}50(41 . \\
7)\end{array}$ & $\begin{array}{l}24(20.0 \\
)\end{array}$ & 2.71 & .91 \\
\hline $\begin{array}{l}\text { I need information literacy skill to avoid } \\
\text { plagiarism }\end{array}$ & $\begin{array}{l}14 \\
(11.7)\end{array}$ & $28(23.3)$ & $\begin{array}{l}55(45 . \\
8)\end{array}$ & $23(19.2$ & 2.73 & .91 \\
\hline $\begin{array}{l}\text { I need information literacy skill to effectively use } \\
\text { search engine }\end{array}$ & $7(5.8)$ & $27(22.5)$ & $\begin{array}{l}63(52 . \\
5)\end{array}$ & $23(19.2$ & 2.85 & .80 \\
\hline Weighted average & \multicolumn{6}{|l|}{2.67} \\
\hline
\end{tabular}

Note: percentages are in parentheses

Table 1 above showed the perception of teachers on the need for information literacy among secondary school students in Lagos State. It revealed that majority of the teachers agreed that they need information literacy skill to be an effective teacher (mean $=3.1$ ) while they disagreed with the fact that there is no relationship between their level of information literacy skills and job performance (mean $=1.77$ ). The Table further revealed that majority of the teachers affirmed their need for special training to be able to effectively use the Internet and electronic databases $($ mean $=3.04)$ and $($ mean $=2.97)$ effectively. The teachers also disagreed that they need training for information literacy skill for the effectively use the library (mean $=2.36$ ) but they agreed that they need training for effectively retrieve information in any format from any source (mean $=2.71$ ); to avoid plagiarism (mean $=2.73$ ) and for effective use of search engines (mean $=2.85)$. The weighted average is 2.67 which implies that the teachers have a positive perception towards the relevance of information literacy skills in enhancing their implementation of humanities curricula.

\section{Research question 2:}

What are the academic qualifications and years of teaching experience of teachers handling humanity subjects in senior secondary schools in Lagos State?

Table 2: Respondents distribution based on highest educational qualification

\begin{tabular}{|l|l|l|}
\hline Academic Qualification & Frequency & Percentage (\%) \\
\hline B.Ed & 28 & 23.3 \\
\hline NCE & 22 & 18.3 \\
\hline B.A & 29 & 24.2 \\
\hline PGDE & 4 & 3.3 \\
\hline B.Sc & 23 & 19.2 \\
\hline M.Ed & 12 & 10.0 \\
\hline M.A & 2 & 1.7 \\
\hline Total & 120 & 100.0 \\
\hline
\end{tabular}

Table 2 presents information on the highest qualification of respondents and it revealed that only $36.6 \%$ of the observed teachers were qualified to teach humanity subjects in senior secondary school. That is those with first degree, postgraduate diploma (PGDE) and Masters in education. All other (63.4\%) were not qualified to teach at this level of education. That is, those with NCE, degree in Arts and Sciences and Master degree in Arts. Figure below depict this information. 


\section{Academic Qualification}

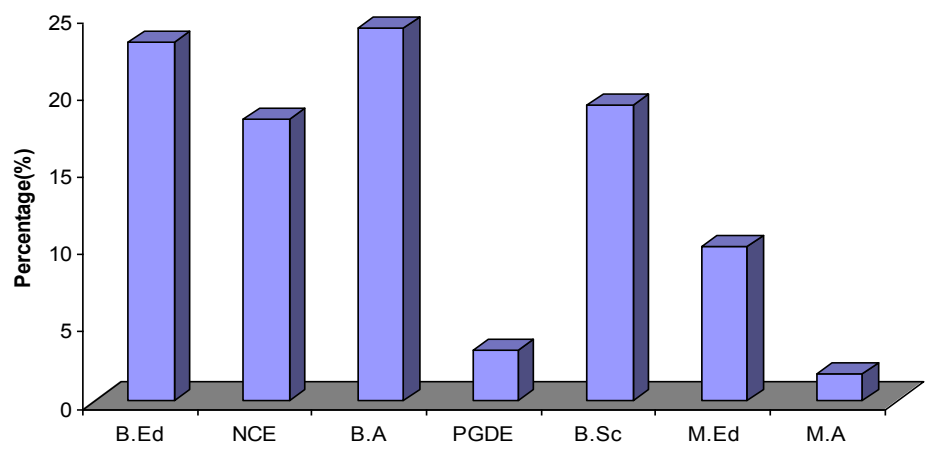

Figure 4: Distribution of respondents based on highest qualification

Table 3: distribution of the Teacher Based on Years of Teaching Experience

\begin{tabular}{|l|l|l|}
\hline Year of teaching experience & F & $\%$ \\
\hline $1-5$ & 49 & 40.8 \\
\hline $6-10$ & 27 & 22.5 \\
\hline $11-15$ & 29 & 24.2 \\
\hline $16-20$ & 9 & 7.5 \\
\hline $21-25$ & 2 & 1.7 \\
\hline $26-30$ & 4 & 3.3 \\
\hline Total & 120 & 100.0 \\
\hline
\end{tabular}

Table 3 presents the distribution of respondents based on the years of working experience of respondents. It showed that majority of the respondents $(59.2 \%)$ has been working for an upward of 6 years and above. This implies that the teachers in the selected secondary schools are experienced teachers that have been working for a reasonable number of years. Figure 2 below depict this information in bar chart.

Years of Experience

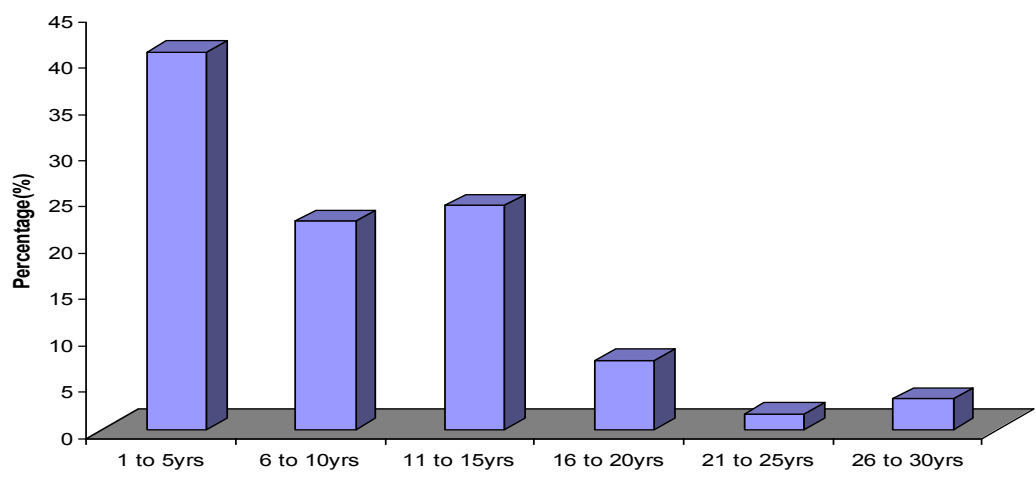

Fig 4.3: Distribution of respondents based on years of working experience

With all these, it can now be inferred that larger proportion of the teachers were not qualified to be teaching humanity subjects at senior secondary school level and little above average number of the teacher have been working for more than five years.

Research Question 3: what proportion of humanity subject teachers in Lagos State senior secondary school are professionally qualified?

Based on table 3 above, it is only 36.6 percent of the teachers teaching humanity subjects in Lagos State are professionally qualified to be teaching the subjects at that level of education

Research Question 4: Do the humanity subject teachers in Lagos State possess information literacy skills, that is:

a. Ability to identify when information is needed 
b. Ability to identify sources of information

c. Ability to access information and

d. Ability to utilize information

Table 4: Teachers' opinion on information literacy skills possessed.

\begin{tabular}{|l|l|l|}
\hline Statement & F & $\%$ \\
\hline Ability to determine when information is needed & 53 & $(44.2)$ \\
\hline Ability to access the needed information effectively and efficiently & 47 & $(39.2)$ \\
\hline Ability to evaluate information and its services critically & 32 & $(26.7)$ \\
\hline Ability to use information effectively to accomplish a specific goal & 51 & $(42.5)$ \\
\hline Ability to understand ethical use of information & 17 & $(14.2)$ \\
\hline Ability to identify potential sources of information & 61 & $(50.8)$ \\
\hline Ability to evaluate needed information & 27 & $(22.5)$ \\
\hline Ability to integrate new information to existing body of knowledge & 49 & $(40.8)$ \\
\hline Ability to develop successful search strategy & 59 & $(49.2)$ \\
\hline Ability to retrieve information in any format from any source & 18 & $(15.0)$ \\
\hline
\end{tabular}

Table 7 presented information on the teachers' response on the possession of relevant information literacy skill. It revealed that only $(44.2 \%)$ of the teachers possess the skill of determining when information is needed for the implementation of the curriculum; only $39.2 \%$ possess the skill of accessing information; $50.8 \%$ have the skill of identify the sources of information and only 42.5 possess the ability to use information for the benefits of curriculum implementation.

Research Question 5: What type of information resources do the humanity teachers access for teaching purpose?

Table 5: Information Resources Accessed By Humanity Teachers for Teaching Purpose

\begin{tabular}{|l|l|l|}
\hline Resources & Yes (\%) & No (\%) \\
\hline Online public access catalogue (OPAC) & $26(21.7)$ & $94(78.3)$ \\
\hline Web locator & $30(25)$ & $90(75.0)$ \\
\hline Electronic journals & $36(30.0)$ & $84(70.0)$ \\
\hline Digital Library & $38(31.7)$ & $82(68.3)$ \\
\hline Electronic Databases & $40(33.3)$ & $80(66.7)$ \\
\hline Microsoft office tools & $78(65.0)$ & $42(35.0)$ \\
\hline Internet resources & $68(56.7)$ & $52(43.3)$ \\
\hline Current Awareness Bulletin & $44(36.7)$ & $76(63.3)$ \\
\hline Computer System & $87(72.5)$ & $33(27.5)$ \\
\hline CD-ROM Search & $46(38.3)$ & $74(61.7)$ \\
\hline Web 2.0 & $17(14.2)$ & $103(85.8)$ \\
\hline
\end{tabular}

Table 5 above presented information on the resources accessible to the teachers of humanity subject teachers in Lagos State. It is revealed that the resources commonly accessible to the teachers are computer system (72.5\%); microsoft office tool $(65.0 \%)$; internet resources $(56.7 \%)$. Other resources are not commonly accessible to the teachers in Lagos State.

\section{Testing the Null Hypotheses}

$\mathrm{H}_{01}$ :- There is no significant relationship between humanity teacher's perception of importance of information literacy to secondary school humanity subject teaching and their information literacy skills.

Table 4.10: summary of Pearson Product-Moment Correlation showing Relationship between Teachers' perception and their information literacy skills

\begin{tabular}{|l|l|l|l|l|l|l|}
\hline Variables & $\mathrm{N}$ & Mean & Std. Dev & R & Sig. & Remark \\
\cline { 1 - 5 } Perception of relevance & 120 & 23.98 & 4.63 & .092 & .318 & Not sig. \\
\hline Infor. Literacy skills & 120 & 6.10 & 3.13 & & & \\
\hline
\end{tabular}

Table 4.10 reveals that there is no significant relationship between the humanity subject teachers perception of relivance of information literacy skills and their level of information literacy skills $(r=0.092 ; \mathrm{P}>0.05)$. Therefore, the null hypothesis 1 is not rejected. This implies that what the teachers perceived about information literacy skills did not influence the level of information literacy the possessed. 
$\mathrm{H}_{02}$ :- There is no significant relationship between humanity teacher's perception of importance of information literacy to secondary school students and the utilization of information literacy skill on the implementation of humanity curricula.

Table 4.11: summary of Pearson Product-Moment Correlation showing Relationship between Teachers' perception and their utilization of information literacy skills

\begin{tabular}{|l|l|l|l|l|l|l|}
\hline Variables & $\mathrm{N}$ & Mean & Std. Dev & $\mathrm{R}$ & Sig. & Remark \\
\hline Perception of relevance & 120 & 23.98 & 4.63 & $.228^{*}$ & .012 & Significant \\
\hline Use of info. Lit. skills & 120 & 17.75 & 3.04 & & & \\
\hline
\end{tabular}

Table 4.11 reveals that there is a significant, positive relationship between the teachers perception of importance of information literacy skills and their utilization of the information literacy skills $(\mathrm{r}=0.228 ; \mathrm{P}<0.05)$. Therefore, the null hypothesis 2 is rejected. The positive relationship implies that the better the perception of importance, the more the utilization of the skills of information literacy.

$\mathrm{H}_{03}$ : There is no significant relationship between humanity teacher's access to information literacy and the utilization of information literacy skill on the implementation of humanity curricula in senior secondary schools in Lagos State

Table 4.12: Summary of Pearson Product-Moment Correlation showing Relationship between Teachers' access to information literacy resources and their Utilization of it

\begin{tabular}{|l|l|l|l|l|l|l|}
\hline Variables & $\mathrm{N}$ & Mean & Std. Dev & $\mathrm{R}$ & Sig. & Remark \\
\cline { 1 - 4 } Access to infor. Lit resources & 120 & 6.10 & 3.13 & $.217^{*}$ & .017 & Significant \\
\cline { 1 - 4 } Use of info. Lit. skills & 120 & 17.75 & 3.04 & & & \\
\end{tabular}

Table 4.12 reveals that there is a positive significant relationship between teachers of humanity subjects access of information literacy resources and their use of information literacy skills $(r=0.217 ; \mathrm{P}<0.05)$. Therefore, the null hypothesis 3 is rejected. The positive relationship implies that the more accessibility of the information resources, the more the utilization of the information literacy skills.

$\mathrm{H}_{04}$ : - There is no significant relationship between humanity teacher's information literacy acquisitions and the utilization of information literacy skill on the implementation of humanity curricula in senior secondary schools in Lagos State

Table 4.13: Summary of Pearson Product-Moment Correlation Showing Relationship Between Teachers' Acquisition of Information Literacy Skills and the Utilization of the Skills

\begin{tabular}{|l|l|l|l|l|l|l|}
\hline Variables & $\mathrm{N}$ & $\mathrm{Mean}$ & Std. Dev & $\mathrm{R}$ & Sig. & Remark \\
\hline Infor. Lit. acquisition & 120 & 8.62 & 1.20 & .086 & .350 & Not sig. \\
\hline Use of info. Lit. skills & 120 & 17.75 & 3.04 & & & \\
\hline
\end{tabular}

Table 4.13 shows that there is no significant relationship between the acquisition of information literacy skills and the teachers utilization of the skills $(\mathrm{r}=0.086 ; \mathrm{P}>0.05)$. Therefore, the null hypothesis 4 is not rejected. This implies that the level of acquiring the skills has not been influencing the use of the skills.

\section{Conclusion}

Based on the data analysis and the interpretation done, the following are the conclusion of the findings.

1) Teachers in Lagos State senior secondary schools have a positive perception towards the relevance of information literacy skills in enhancing their implementation of humanities curricula.

2) Research revealed that only $36.6 \%$ of the observed teachers were qualified to teach humanity subjects in senior secondary school. That is those with first degree, postgraduate diploma (PGDE) and Masters in education.

3) Majority of the respondents (59.2\%) has been working for an upward of 6 years and above. This implies that the teachers in the selected secondary schools are experienced teachers that have been working for a reasonable number of years.

4) Only 36.6 percent of the teachers teaching humanity subjects in Lagos State are professionally qualified to be teaching the subjects at that level of education

5) It revealed that only (44.2\%) of the teachers possess the skill of determining when information is needed for the implementation of the curriculum; only $39.2 \%$ possess the skill of accessing information; $50.8 \%$ have 
the skill of identify the sources of information and only 42.5 possess the ability to use information for the benefits of curriculum implementation.

6) It is revealed that the resources commonly accessible to the teachers are computer system $(72.5 \%)$; microsoft office tool (65.0\%); internet resources (56.7\%). Other resources are not commonly accessible to the teachers in Lagos State.

\section{The Result of the Hypothesis shows the following:}

1) The Relationship between Teachers' perception and their information literacy skills implies that what the teachers perceived about information literacy skills did not influence the level of information literacy the possessed.

2) Relationship between Teachers' perception and their utilization of information literacy skills shows positive relationship this implies that the better the perception of importance, the more the utilization of the skills of information literacy.

3) Relationship between Teachers' access to information literacy resources and their Utilization of it shows positive relationship this implies that the more accessibility of the information resources, the more the utilization of the information literacy skills.

Relationship between Teachers' Acquisition of Information Literacy Skills and the Utilization of the Skills implies that the level of acquiring Information Literacy skills has not been influencing the use of the skills.

\section{Reference}

[1]. American Library Association 2000. Information literacy Competency Standards for Higher Education. Retrieved on $30^{\text {th }}$ November, 2010 form http://www.ala.org/ala/mgrps/divs/acrl/standards/informationliteracycompetency.cfm

[2]. American Library Association and Association for Educational Communications and Technology. 1998. Information Power: Building Partnerships for Learning Roles and Responsibilities of the School Library Media Specialist.

[3]. Asselin, M. and Moayeri M. 2010. New tools for new literacies research: an exploration of usability testing software. International Journal of Research and Method in Education , 33 (1), $41-53$.

[4]. Behrens, Shirley J. 1990. Literacy and the Evolution towards Information Literacy: An Exploratory Study. South African Journal of Library and Information Science, Vol.58 No. 4. P. 355

[5]. Candy, Philip C. 1993. The Problem of Currency: Information Literacy in the Context of Australia as a Learning Society. The Australian Library Journal, Vol.42 No.(4) p.290

[6]. CILIP [Chartered Institute of Library and Information Professionals]. 2004. Information Literacy: Definition. Available form http://www.cilip.org.uk/policyadvocacy/informationliteracy/definition/default.htm

[7]. Duggan, A., Hess, B., Morgan, D., Kim, S., and Wilson, K. 2001. Measuring student' attitude toward educational use of the int ernet. Journal of Educational Computing Research, 25(3), 267 -281

[8]. Hancock, Vicki E. 2003. Information Literacy for Lifelong Learning. http://www.libraryinstruction.com/information-literacy.html

[9]. Mokhtar, Majid and Foo (2004). Measuring infromation literacy in education.

[10]. Procceding. Conference on Information Literacy: Information, Learning, Innovation: Delivering Global Knowledgehttp://www3.ntu.edu.sg/home/sfoo/publications/2004/2004CILLLI fmt.pdf Date retrieved 12/05/2011

[11]. Obama, Barak. 2009. National Information Literacy Awareness Month: President proclaims National IL Awareness Month... Communication Information Literacy Blog

[12]. Pago, K., and Wallace, C. (2001) Barriers to the uptake of web-based technology by university teachers. Journal of Distance Education, $16(1), 70-84$

[13]. Rockman, I. F. 2004. Introduction: the importance and information literacy.

[14]. Retrieved on the 20/04/2011 from http://media.wiley.com/product_data/excerpt/78/07879652/0787965278.pdf 